\title{
MYCOTOXICOSES OF POULTRY CAUSED BY TRICHOTHECENES
}

\author{
D. Jakić-Dimić ${ }^{1}$ K. Nešić ${ }^{1}$, D. Šsefer ${ }^{2}$ \\ ${ }^{1}$ Institute of Veterinary Medicine of Serbia, Belgrade, Republic of Serbia \\ ${ }^{2}$ Faculty of Veterinary Medicine, Belgrade University, Republic of Serbia \\ Corresponding author: nivs@nivs.rs \\ Review paper
}

Abstract: Recent mycological and mycotoxicological analysis of many feed samples have shown that this problem is still present. It is approved that mouldy feed can contain various mycotoxins, but in our conditions among the most investigated and usually present are some trichotecenes. Based on laboratory feed inspection of samples sent to be analysed in the Institute of Veterinary Medicine of Serbia in Belgrade it was concluded that fungi and mycotoxins contamination are common. Although detected levels usually do not exceed limits layed by actual legislation, having on mind cumulative effects and possible chronical exposure of animals to their harmful influence, appropriate and competent approach is necessary. In fact, even when direct loses, as consequence of high mortality are not present, indirect loses due to drop of performances and production and higher incidence of other deseases must not be neglected.

Key words: feed, fungi, mycotoxins

\section{Introduction}

One of the most challenging aspects of diagnosing cases of suspected mycotoxicoses is collecting a feed sample that adequately represents the feed suspected of being contaminated. Mycotoxins are not evenly distributed in feeds, so the contaminated part of the feed may be consumed before disease is evident. Collection of meaningful feed specimens under such conditions is very difficult.

Interpreting the significance of mycotoxins present in the ration is difficult also. If high concentration of mycotoxin is detected in feed, the disease it causes should match the clinical syndrome. But, especially in chronic forms, amount of mycotoxin in the feed is not that significant and, as a result of synergistic effect of different mycotoxins, only non-specific symptoms occur (Jakic-Dimic et al., 2009a).

Treatment of animals suffering from mycotoxicoses usually is supportive and often not very effective. Antidotes for mycotoxins are generally not available. 
Stopping and preventing further exposure by removing contaminated feed is important. It is not uncommon for animals to improve after they quit eating feed suspected or known to be contaminated with mycotoxins. Such an occurrence supports the suspicion of the feed as a causal factor, but does not prove that the animals suffered from a mycotoxicosis (Carlson and Ensley, 2003).

From the toxicological and economical point of view, five mycotoxin groups are currently significant worldwide. Among them are trichothecenes produced by Fusarium species which contaminate cereals already in the fields. Trichothecenes play an important role in the pathology of poultry, especially T-2 toxin, DAS and crotocine. Most of the damages: lesions and production of yellow caseous sediments at the edges of the beak, mucosa, hard palate and tongue, develop as a consequence of prolonged feeding with such mycotoxins' contaminated feed (Jakic-Dimic and Nesic, 2009a; 2009b). Depending on dosage and exposition time to mycotoxins, intoxication may be acute, caused by high doses of mycotoxins intake, or chronic, resulting from long term low dose of mycotoxin intake (Trenholm et al., 1985).

\section{Chickens}

Oral lesions, circumscribed and proliferative plaques can be noticed after two weeks of feeding with 4-8 mg/kg T-2 toxin and after three weeks in hens fed $0.5 \mathrm{mg} / \mathrm{kg}$ (Gupta, 2007). Combination of effects of multiple trichothecenes, and/or trichothecenes and other mycotoxins, which can be found in naturally contaminated and mouldy chicken feed, cause much more symptoms than those which arise from one mycotoxin (Sinovec et al., 2006). In feed samples for poultry analysed by Jakic-Dimic et al. (2009b) T-2 toxin did not exceeded maximum levels specified in national regulations $(0.5 \mathrm{mg} / \mathrm{kg}$ for young and $1.0 \mathrm{mg} / \mathrm{kg}$ for adult poultry). During five years period detectable levels of this toxin were found in $5,4 \%$ of poultry feed samples (Jakic-Dimic et al., 2010).

The first significant sign of trichothecenes' presence is feed refusal that appears in fattening chickens and other poultry and that is the phenomenon that farmers often emphasize. This symptom usually disappears after the removal of such feed, but the diagnosis is rarely determined. However, there is a belief that the cause of the decline in feed consumption is the consequence of the presence of Fusarium fungi and their mycotoxins (Osweiler et al., 1985).

The presence of T-2 toxin, especially T-2 tetraol which is derivate of T-2 toxin, exerts cytotoxic effect that is especially present in macrophages. Systemic effects can occur with necrosis of epithelial tissue and suppression of hematopoiesis. Kid et al. (1997) found that the T-2 toxin causes a hemorrhagic disorder, disturbing the biochemical mechanism of blood coagulation in poultry with primary effect on coagulation factor VII and the secondary effect on 
prothrombin and fibrinogen. This toxin significantly prolonged prothrombin clotting time in poultry.

As the associated symptoms gastrointestinal effects, mild diarrhea, grouping, sometimes irritability and fatigue, ataxia, uncoordinated movements, falling away are observed. In younger birds, there is bad feathering, poor feather quality and soft bones. Subcutaneous edema and degeneration of the neck muscles may also be present (Davis, 1994; Reddy, 2007). As with other animals, the presence of this toxin leads to reduced consumption and increased feed conversion as well as retarded growth. Huff et al. (1988) have shown the synergistic effect of T-2 toxin and aflatoxin, which amplified the effect of each other. Decrease of egg production can be 50 to $75 \%$. Increase of eggshell breakage up to $20 \%$. Sporadically there are egg spots with frequency up to about $3 \%$. This was confirmed by Hoerr et al. (1982) who found that this toxin causes severe lesions in the mouth, salivary glands and tongue where a yellowish pseudomembranes are formed and after there removal lesions remain.

Diacetoxyscirpenol (DAS) from feed causes oral necrosis in chickens, decrease weight gain up to $24 \%$ depending on the amount present in the diet. Diaz et al. (1994) reported a significant decrease in egg production and feed intake in commercial layers fed a diet containing $2 \mathrm{mg} / \mathrm{kg}$ DAS for 24 days. Oral lesions are more serious than lesions caused by T-2 toxin. Diacetoxyscirpenol (DAS) presence is often manifested by liver enlargement with the signs of metemorphosis and necrobiosis, enlargement of gall bladder, seminal duct epithel degeneration, tubulonephrosis, perivascular edema of brain and depletion of lymphocytes in the thymus tissue and Bursa of Fabricius. Crotocine as one of the trichothecenes, besides T-2 toxin and diacetoxyscirpenol (DAS), causes oral necrosis and decreases weight gain of fattening chickens.

\section{Ducks}

Davis et al. (1994) examined impact of mycotoxins in Beijing ducks . They noted that mortality caused by trichotecene deoxynivalenol (DON) in concentration $300-1176 \mathrm{ppb}$ caused hundred percent mortality in case of the greatest concentration of mycotoxin and $29 \%$ at the lowest concentration. An autopsy determined dehydration and hemorrhage along the intestinal epithelium. Rafai et al. (2000) reported that T-2 toxin reduced body weight, altered serum and plasma chemical values and haematological parametars in white Pekin ducks.

Scott and Dean (1991) found that mycotoxicosis have an impact on a reduced production of eggs of ducks and that, depending on the concentration of mycotoxin, significant mortality can occur, while the ducks are especially sensitive to the toxic effects of deoxynivalenol. 


\section{Geese and turkeys}

Vanyi et al. (1994) studied the harmful effects of T-2 toxin in geese laying hens and gander. In geese was observed drastic decrease in egg production. At autopsy were found degenerative changes in the ovaries, the interruption of maturation of follicles and their degeneration occurred as the result of mycotoxins. There was a peritontis, bleeding, wrapped oviducts, necrosis, spleen amilodosis and cataral enteritis. Signs of thyroid colloid stasis were found and in cytoplasm of a large number of secretory glands that produce adrenaline as well. In gander toxin did not reduce the intensity of sperm production, but changes in other organs were identical as in geese. Vomitoxin in the concentration of $5 \mathrm{mg} / \mathrm{kg}$ does not cause disease in turkeys, but a higher concentration causes changes very similar with other poultry.

\section{Pigeons and pheasants}

In pigeons was also found this type of intoxication, but it is clinically manifested in a much lower percentage than in other poultry. It turned out that the young just hatched birds are more sensitive than older animals and that the possibility of death in this group of pigeons is higher. The most frequent is T-2 toxicosis, mainly due to the granular nutrients that doves are getting. The clinical picture of T-2 toxicosis is similar to chickens: presence of the yellow caseous proliferations in the form of deposits along the edges of the beak, around the mouth and at the mucosa of the palate and tongue (often can be replaced with hystomoniasis). In young birds bad feathering and poor quality of feathers is present, which affects the competitive results, especially in pigeons. T2 causes vomiting in pigeons at doses of one fifth or less the $\mathrm{LD}_{50}$ (Fairhurst et al., 1987). Mouth lesions were seen in some of the pheasants fed T-2 toxin as well as increase of feed conversion ratio (Huff et al., 1992).

\section{Conclusion}

Fusarium fungi are very common in our climate conditions and among their secondary metabolites trichotecenes are of most frequent. They play an important role in the pathology of poultry. By improvement of the quality of grain storage and production (lower humidity, good ventilation ...) it is possible to reduce the synthesis of mycotoxins, which is one of the most important aspects of prevention of this problem. Feed analysis should be often done and lower levels of mycotoxins must not be neglected. The risk of rigid interpretation of the regulations also remains, as it is well known that the use of feed with low content 
of mycotoxins in the longer time period shows similar effects as short-term use of feed with higher amount of mycotoxins. The problem is getting more complicated as the interaction of different mycotoxins present in feed increases harmful effects. Therefore, the assessment of utilization of feed should be still dependant on the institutions and experts that this problem is one of the special scientific and professional activities.

\title{
Acknowledgment
}

Research was financed by the Ministry of Education and Science, Republic of Serbia, projects III 46009.

\section{Mikotoksikoze živine prouzrokovane trihotecenima}

\author{
D. Jakić-Dimić, K. Nešić, D. Šefer
}

\section{Rezime}

Fusarium plesni preovlađuju u našem regionu.

Među mikotoksinima koje proizvode Fusarium plesni, živina je naročito osetljiva na T-2 toksin i DAS koji pripadaju grupi trihotecena. Mlada živina, uzgojna živina, patke i golubovi često su osetljiviji na efekte mikotoksina.

Kombinacija više različitih vrsta mikotoksina može da dovede do težih efekata čineći problematičnijim definisanje sigurnih nivoa u hrani.

$\mathrm{U}$ cilju prevencije problema $\mathrm{u}$ vezi sa prisustvom mikotoksina $\mathrm{u}$ hrani neophodno je pravilno skladištenje i rukovanje žitaricama i gotovom hranom kako bi se smanjio razvoj plesni i produkcija mikotoksina. Takođe, neophodno je vršiti i redovne analize za detekciju mikotoksina.

Dodaci hrani za životinje mogu da se koriste za ublažavanje štetnih efekata nekih mikotoksina, ali treba da budu istraženi kako bi njihova aktivnost bila usmerena na mikotoksin od interesa.

\section{References}

CARLSON M.P., ENSLEY S.M. (2003): Understanding Fungal (Mold) Toxins (Mycotoxins), NebGuide G1513, http://extension.unl.edu/publications.

DAVIS G.S., ANDERSON K.E., PARKHURSTD C.R., RIVESB HAGLER W.M. (1994): Mycotoxins and feed refusal by Peking duck. J. Appl. Poultry Res., 3, 190-192. DIAZ G.J., SQUIRES E.J., JULIAN R.J., BOERMANS H.J. (1994): Individual and combined effects of $\mathrm{t}-2$ toxin and DAS in laying hens. Br. Poult. Sci., 35, 393-405. 
FAIRHURST S., MARRS T.C., PARKER H.C., SCAWIN J.W., SWANSTON D.W. (1987): Acute toxicity of T2 toxin in rats, mice, guinea pigs, and pigeons. Toxicology, 43, 1, 31-49.

GUPTA R. (2007): Trichothecenes in: veterinary toxicology, basic and clinical principles. Ac. press Elsevier, NY, USA, 951-976.

HOERR F.J., CARLTON W.W., TUITE J., VESONDER R.F., ROHWEDDER W.K., SZIGETI G. (1982): Experimental trichothecene mycotoxicosis produced in broiler chickens by Fusarium sporotrichiella var. sporotrichioides. Avian Pathology, 11, 385-405.

HUFF W.E., HARVEY R.B., KUBENA L.F., ROTTINGHAUSE G.E. (1988): Toxic synergism between aflatoxin and T-2 toxin in broiler chickens. Poult Sci, 67, $10,1418-1423$.

HUFF W.E., RUFF M.D., CHUTE M.B. (1992): Characterization of the toxicity of the mycotoxins aflatoxin, ochratoxin, and T-2 toxin in game birds. II. Ringneck pheasant. Avian Dis., 36, 1, 30-3.

JAKIC-DIMIC D., NESIC K., PETROVIC M. (2009a): Contamination of cereals with aflatoxins, metabolites of fungi Aspergillus flavus. Biotechnology in Animal Husbandry, 25, 5-6, 1203-1208.

JAKIC-DIMIC D., NESIC K., PETROVIC M. (2009b): Mycotoxins in feed for pigs and poultry, Biotechnology in Animal Husbandry, 25, 5-6, 1149-1154.

JAKIC-DIMIC D., NESIC K. (2009a): Mycotoxins in feed. Proceedings of the XIII Symposium Feed Technology, Novi Sad, 29.09.-01.10.2009, 90-101.

JAKIC-DIMIC D., NESIC K. (2009b): Secondary metabolites of molds as cause of mycotoxicoses in animals. Microbiologia Balkanica Book of abstracts of the 6th Balkan Congress of Microbiology, Ohrid, Macedonia, 28-31.10.2009, 67.

JAKIC-DIMIC D., NESIC K., SAVIC B., KECKES J., PISINOV B. (2010): Presence of fungi in poultry feed and effects of contaminants on health status.

Proceedings of the XIV International Symposium Feed Technology, Novi Sad, 19.10.-21.10.2010, 248-253.

KIDD M.T., QURESHI M.A., HAGLER, W.M.JR., ALI R. (1997): Research notes T-2 tetraolis cytotoxic to a chicken macrophage cell line. Poultry Science, 76, 311-313. LOGRIECO A.F. (2011): Main mycotoxin concerns in Europe: MycoRed and ISM efforts to harmonize strategies for their reduction in food and feed chain. Prezentacija na skupu "Mycology, mycotoxicology and mycoses", Novi Sad, 2022.04.2011.

OSWEILER D., CARSON T., BUCK B., VAN GELDER A. (1985): Veterinary toxicology. 3rd ed., Kendal/Hunt, Iowa, USA.

RAFAI P., PETTERSSON H., BATA A., PAPA Z., GLAVITS S., TUBOLYS S., VANYI A., SOOSS P. (2000): Effect of dietary T-2 fusariotoxin concentrations on the health and production of white Pekin duck broilers. Poult. Sci., 79, 1548-1556. 
REDDY S.M. (2007): Trichothecenes and poultry diseases, In: MOHIUDDIN S.M. (ed.), Moulds and mycotoxins in poultry diseases. Lucknow, International Book, 2007, viii, $284 \mathrm{p}$.

SCOTT M.L., DEAN W.F. (1991): In: Nutrition and Management of Ducks. M.\&. Scott, Ithaca, NY, 150-166

SINOVEC Z., RESANOVIĆ R., SINOVEC S. (2006): Mikotoksini, pojava, efekti i prevencija. Fakultet veterinarske medicine, Univerzitet u Beogradu.

TRENHOLM H.L., THOMPSON B.K., HARTIN K.E., GREENHALGH R., MCALLISTER A.J. (1985): Ingestion of vomitoxin (deoxynivalenol)contaminated wheat by nonlactating dairy cows. J. Dairy Sci., 68, 1000.

VANYI A., BATA A., KOVACS F. (1994): Effects of T-2 toxin treatment on the egg yield and hatchability in geese. Acta Veterinaria Hungarica, 42, 1, 79-85.

Received 30 June 2011; accepted for publication 15 August 2011 